\title{
Nachrichten.
}

\section{An die Redaction eingegangene Schriften.}

(Siehe Jahrg. 1881, Seite 111 u. 112.)

1638. Ant. Reichenow. Vogelbilder aus fernen Zonen, I. Theil Papageien. Lief. 7 [Verlag von Th. Fischer in Cassel]. Von der Verlagshandlung.

1639. Dr. G. Hartlaub. Beitrag zur Ornithologie der östlichaequatorialen Gebiete Africas [Separatabdr. aus Abhandl. des Naturwiss. Vereins zu Bremen. VII. Band, 2. Heft. Bremen 1881]. - Vom Verfasser.

1640. The Ibis. A Quarterly Journal of Ornithology. Edited by Salvin and Sclater. Fourth Series. Vol. V, No. 18, April 1881. - Von der British Ornitholog. Union.

1641. G. Hartlaub. On some new Birds discovered and collected by Dr. Emin Bey in Central-Africa etc. Cum Tab. LX. 1. Eminia lepida, 2. Drymocishla incana [From Proc. Z. S. London, 10. Nov. 1880] - Vom Verfasser.

1642. W. A. Forbes. On some Points in the Structure of Nasiterna bearing on its Affinities [From Proc. Zool. Soc. London, 17. Februar 1880]. - Vom Verfasser.

1643. Forbes. Contributions to the Anatomy of Passerine Birds. Part. I. On the Structure of the Stomach in certain Genera of Tanagers [From Proc. Z. S. London, 2. March 1880]. - Von Demselben.

1644. Forbes. Contributions to the Anatomy of Passerine Birds. Part. II. On the Syrinx etc. of Eurylaemidae [From Pr. Z. S. London, 4. May 1880]. - Von Demselben.

1645. Forbes. Contribut. Anatomy Passerine Birds. Part III. On the Structure of Philepitta and its Position amongst the Passeres [From Pr. Z. S. London, 4. May 1880]. Von Demselben.

1646. Forbes. On the Anatomy of Leptosoma discolor [From Pl. Z. S. London, 15. June 1880]. - Von Demselben.

1647. Forbes. On two rare Ploceine Birds now or lately living in the Societys Menagerie. Cum Tab. XLVII. 1.Vidua splendens, 2. Pytelia Wieneri [From Proc. Z. S. London, 15. June 1880]. - Von Demselben.

1648. Forbes. Note on a Specimen of Denhams Bustard (Eupodotis Denhami) [From Proc. Zool. Soc. London, 15. June 1880]. - Von Demselben.

1649. Forbes. On the Contributions to the Anatomy and Classification of Birds made by the late Prof. Garrod [From The Ibis, Januar 1881]. - Von Demselben. 